\title{
PENGARUH REGENERASI KOTA TERHADAP KUALITAS LINGKUNGAN PERMUKIMAN INDUSTRI KECIL BATIK STUDI KASUS: KAWASAN PABEAN, KOTA PEKALONGAN
}

\author{
Hari Sucahyo ${ }^{1}$ \\ Wisnu Pradoto 2 \\ Kementerian Desa, Pembangunan Daerah Tertinggal dan Transmigrasi ${ }^{1}$ \\ Departemen Perencanaan Wilayah dan Kota, Universitas Diponegoro ${ }^{2}$ \\ Penulis Korespondensi e-mail : hrsucahyo@gmail.com
}

\begin{abstract}
The development of Pekalongan city is rapidly due to its strategic location in the northern coast of Java and the establishment of a world heritage of Batik, so that it gives an influence on all aspects, especially social and economic. Pabean as one of the centers of the home-based batik industry in Pekalongan also played a role in the development of batik, but the existence of the tidal disaster coupled with the lack of conscious entrepreneurs in waste processing has made settlements at Pabean in a declining environmental quality. Regional recovery programs have been present with the aim of returning the function of settlement infrastructure and facilities in Pabean. This study seeks to examine how much influence the urban regeneration has on the quality of the residential environment in Pabean. Three independent variables which constitute the concept of urban regeneration, namely social relations, participation of the private sector and the government in maintaining environmental quality, and the relationship between the public and private sectors and the government are tested on one dependent variable, namely the quality of the housing environment using the method of multiple linear regression analysis, known the results of the effects of urban regeneration of 14.29 percent affect the quality of the housing environment in Pabean.
\end{abstract}

Keywords: urban regeneration, pekalongan, batik, Pabean

\begin{abstract}
ABSTRAK
Perkembangan Kota Pekalongan sangat pesat akibat dari lokasi yang strategis di jalur pantura Pulau Jawa dan penetapan sebagai world heritage of Batik, sehingga memberikan pengaruh terhadap segala aspek khususnya sosial dan ekonomi. Kawasan Pabean sebagai salah satu sentra industri batik rumahan di pekalongan turut berperan dalam perkembangan batik, namun adanya bencana rob ditambah kurang sadarnya pengusaha dalam pengolahan limbah membuat permukiman di Pabean secara kualitas lingkungan menurun. Program pemulihan kawasan telah beragam hadir di Pabean dengan tujuan mengembalikan fungsi prasarana dan sarana permukiman di Pabean. Penelitian ini berusaha meneliti seberapa besar pengaruh regenerasi kota terhadap kualitas lingkungan permukiman di Pabean. Tiga variabel bebas yang merupakan konsep dari regenerasi kota yakni hubungan sosial masyarakat, peran serta swasta dan pemerintah dalam menjaga kualitas lingkungan, serta hubungan antara masyarakat dengan swasta dan pemerintah diuji terhadap satu variabel terikat yaitu kualitas lingkungan permukiman dengan menggunakan metode analisis regresi linier berganda, diketahui hasil pengaruh regenerasi kota sebesar 14,29 persen mempengaruhi kualitas lingkungan permukiman di Pabean.
\end{abstract}

Kata kunci: regenerasi kota, pekalongan, batik, Pabean 
Jurnal Planologi Vol. 17 No. 2, Oktober 2020

Available : http://jurnal.unissula.ac.id/index.php/psa

\section{PENDAHULUAN}

Regenerasi perkotaan dilakukan karena beberapa hal yang membuat vitalitas suatu kota tersebut dan banyaknya orang yang tinggal di daerah perkotaan yang menjadikan daerah perkotaan menjadi tidak proporsional dan mengalami beberapa masalah seperti kemiskinan, permukiman informal, kekumuhan dan kondisi hidup yang tidak sehat, tingkat kriminalitas yang tinggi, tingginya angka pengangguran, terjadinya diskriminasi, serta rendahnya kualitas hidup. Regenerasi perkotaan adalah sebuah cara komprehensif dalam rangka penanganan permasalahan kota guna mencapai pembangunan yang berkelanjutan (Ardiati, 2017). Regenerasi perkotaan merupakan salah satu bentuk perubahan fisik dalam menciptakan ruang kota. Salah satu isu utama regenerasi perkotaan yang berkelanjutan adalah untuk menarik ruang perkotaan melalui renovasi ruang yang ada, sehingga berkontribusi terhadap peningkatan kualitas hidup masyarakat. Oleh karenanya diharapkan bahwa di setiap daerah harus ada rencana untuk sebuah visi masa depan ruang perkotaan yang akan menerapkan secara efektif dan kreatif berbagai macam tindakan seperti pelestarian dan pemanfaatan bangunan bersejarah, rekonstruksi dan perbaikan struktur tua, penciptaan pejalan kaki yang aman dan nyaman serta sepeda lingkungan, pembangunan taman dan ruang terbuka, penciptaan indah lanskap, penyediaan fasilitas masyarakat, pertimbangan lingkungan dan pemeliharaan ruang publik yang aman dan bersih.

Kawasan Pabean yang berada di Kota Pekalongan bagian utara tepatnya di kelurahan Padukuhan Kraton, merupakan kawasan yang terdampak bencana rob dikarenakan berada di tepi laut jawa dan kontur wilayah yang berupa cekungan. Menurut (Doxiadis, 1970), permukiman (human settlement) akan berjalan dengan baik jika terkait dengan lima unsur eksistik, yaitu alam (nature), manusia (man), kehidupan sosial (society), ruang (shells), dan hubungan (networks). Kondisi lingkungan di Pabean sangat memprihatinkan dengan adanya industri batik yang menghasilkan limbah tanpa diolah dan langsung dibuang melalui drainase permukiman, dengan posisi kawasan yang dikelilingi air rob serta kondisi sanitasi yang tidak memadai menarik perhatian pemerintah untuk melakukan revitalisasi pada kawasan Pabean yang telah lama menjadi sentra industri batik. Melihat potensi sosial dan ekonomi yang ada di kawasan itu, maka program peremajaan kota di Pabean perlu untuk dapat dikembangkan dengan memperhatikan keberlanjutan kawasan permukiman itu sendiri. 
Kegiatan regenerasi perkotaan telah diterapkan pada intervensi yang signifikan untuk memperbaiki daerah kumuh pada perkotaan (de Magalhães, 2015), upaya regenerasi perkotaan dilakukan untuk meningkatkan kualitas hidup manusia dan merupakan investasi untuk masa depan, yang dalam pelaksanaannya menjadi sangat luas, berkelanjutan, dan sulit namun mungkin untuk diterapkan (Alpopi \& Manole, 2013). Regenerasi perkotaan merupakan salah satu cara baik untuk membenahi dan meningkatkan kawasan yang ada daripada merencanakan perencanaan perkotaan yang baru (Balaban \& Puppim de Oliveira, 2014). Kegiatan regenerasi perkotaan seharusnya berorientasi pada perkotaan yang biasanya melibatkan langkah-langkah perbaikan ekonomi, sosial, dan fisik / lingkungan (Houk et al., 2015), yang bertujuan untuk mengatasi isu-isu yang mempengaruhi daerah perkotaan.

Konsep berkelanjutan merupakan salah satu konsep yang dapat menjadi pemecahan masalah antara industri, permukiman, dan lingkungan yang menjadi perpaduan permasalahan yang ada di kawasan. Konsep pembangunan berkelanjutan memiliki tiga aspek utama yaitu, ekonomi, social, dan lingkungan. Konsep berkelanjutan ini diharapkan dapat tetap mempertahankan eksistensi aktifitas ekonomi yang ada tanpa mengesampingkan kondisi lingkungan dan sosial masyarakatnya (Farr, 2008) berpendapat bahwa konsep berkelanjutan memperhatikan kesempatan besar dalam redesain lingkungan terbangun dalam upaya mendukung peningkatan kualitas hidup dan mempromosikan konsep berkelanjutan itu sendiri.

Beragam bentuk kegiatan regenerasi kota di kawasan Pabean telah dilaksanakan utamanya oleh Pemerintah Daerah melalui Kotaku seperti perbaikan dan peninggian jalan, peningkatan kualitas drainase serta penyediaan sumber air bersih melalui pamsimas dan sebagainya, namun apakah program tersebut sudah efektif bagi seluruh warga Pabean yang terdiri terdiri dari 4 RW? Regenerasi perkotaan memiliki kontribusi paling mendasar terhadap pelaksanaan pembangunan berkelanjutan melalui "daur ulang" lahan dan bangunan, mengurangi limbah pembongkaran dan bahan kontruksi baru, serta memfasilitasi intensifikasi dan kekompakan pada daerah perkotaan yang ada (Turcu, 2012). Roberts et al. (2016) memberikan gambaran mengenai proses interaksi antara satu faktor dengan berbagai faktor lainnya yang digambarkan pada Diagram Gambar 1. Peneliti menggunakan 3 variabel terkait regenerasi perkotaan yaitu variabel hubungan sosial masyarakat yang memiliki fungsi untuk mengamati intensitas konflik yang terjadi dalam masyarakat dan hubungan sosial antar warga, Variabel peran serta swasta dan pemerintah 
dalam menjaga kualitas lingkungan yang berfungsi untuk mengetahui peranan sektor swasta dan peranan pemerintah dalam menjaga kualitas air bersih, jaringan jalan dan drainase, dan variabel hubungan antara masyarakat dengan swasta dan pemerintah yang berfungsi untuk mengetahui keterlibatan masyarakat dalam kegiatan pengelolaan lingkungan yang diinisiasi pemerintah maupun swasta, mengetahui tingkat partisipasi masyarakat dalam kegiatan pengelolaan lingkungan yang diinisiasi oleh pemerintah dan ketersediaan kegiatan pengelolaan lingkungan yang diinisiasi oleh pihak swasta. Ketiga variabel dikaji pengaruhnya terhadap kualitas lingkungan permukiman sehingga akan diketahui seberapa besar pengaruh pelaksanaan regenerasi perkotaan yang telah dilakukan selama ini di Pabean, sehingga dapat memberikan masukan bagi para stakeholder terkait dalam melakukan intervensi pembangunan yang tepat di kawasan Pabean khususnya bagi pemerintah kota setempat.

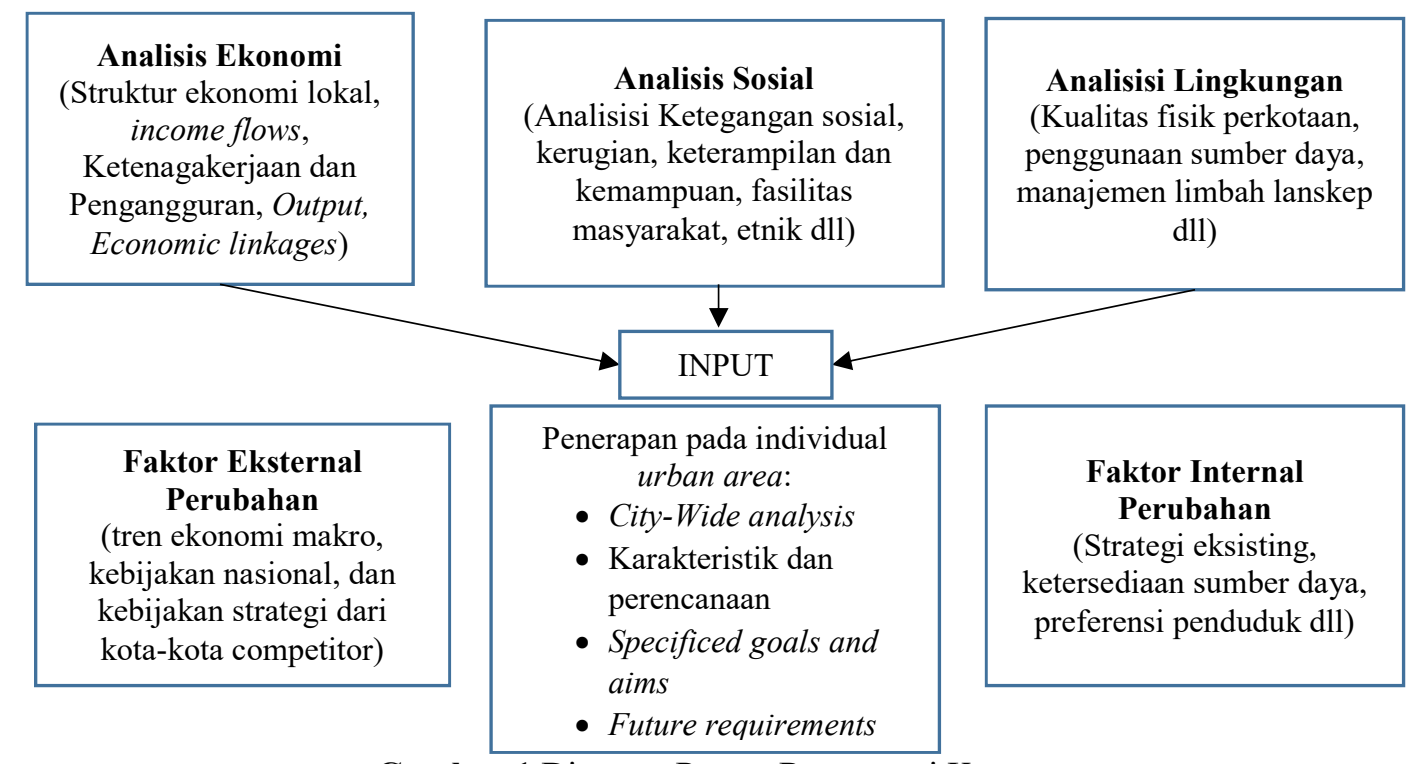

Gambar 1 Diagram Proses Regenerasi Kota

Sumber : Urban Regeneration, a Handbook (Roberts, Sykes, \& Granger, 2000) dalam (Ardiati, 2017)

\section{METODOLOGI}

Penelitian ini menggunakan pendekatan positivisme, dalam penelitian ini menggunakan pendekatan positivisme sosiologi. Positivisme sosiolaogi menurut Comte (1975) lebih menekankan pada pengamatan langsung ke lapangan yakni melakukan observasi terhadap kondisi fisik lingkungan dan kualitas lingkungan permukiman kawasan Pabean. Hasil observasi tersebut diperjelas dengan wawancara dan penyebaran kuesioner. 
Wawancara bertujuan untuk mengkonfirmasi hasil dari jawaban kuesioner, wawancara diajukan secara lisan kepada tokoh masyarakat di kawasan Pabean yakni kelurahan, ketua RW, dan Badan Keswadayaan Masyarakat (BKM). Kuesioner digunakan untuk menjaring pendapat masyarakat Pabean terkait variabel yang digunakan dalam penelitian ini, kuesioner bersifat tertutup, maksudnya jawaban kuesioner telah tersedia dan responden tinggal memilih beberapa alternatif yang telah disediakan. Jumlah sampel yang digunakan sejumlah 92 KK. Hasil dari kuesioner kemudian dilakukan skoring pada masing - masing indikator yang menunjukkan hasil kualitas lingkungan permukiman berdasarkan pendapat masyarakat dengan tingkatan skor baik, sedang, dan buruk. Kemudian untuk mengetahui pengaruh regenerasi perkotaan terhadap kualitas lingkungan permukiman menggunakan analisis regresi linier berganda yang diolah menggunakan SPSS. Variabel bebas yang digunakan terdiri dari hubungan sosial masyarakat, peran serta swasta dan pemerintah dalam menjaga kualitas lingkungan, dan hubungan antara masyarakat dengan swasta dan pemerintah. Ketiga variabel tersebut diujikan dengan satu variabel terikat yakni kualitas lingkungan permukiman sehingga dapat diketahui bagaimana pengaruh yang ditimbulkan oleh regenerasi perkotaan terhadap kualitas permukiman di kawasan industri batik Pabean.

\section{HASIL DAN PEMBAHASAN}

\subsection{Kondisi Fisik lingkungan kawasan Pabean}

Kondisi lingkungan permukiman di Pabean adalah kawasan permukiman yang bercampur dengan industri kecil batik, rumah penduduk beserta sarana dan prasarana di Pabean secara keseluruhan menurut warga masyarakat setempat telah mengalami peninggian 2-3 kali dengan periode peninggian adalah setiap 1-2 tahun dikarenakan peningkatan rob yang menggenangi Pabean.

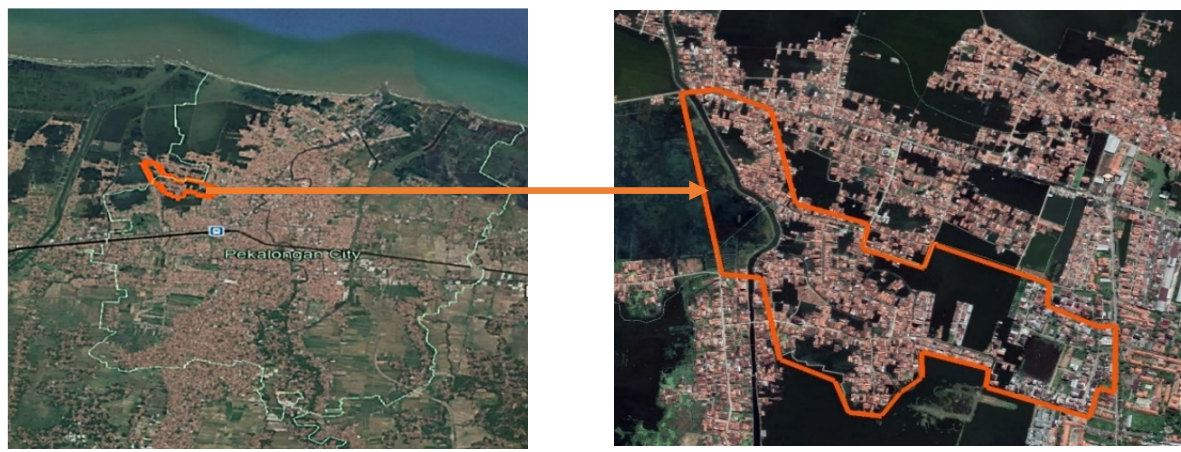

Gambar 2 Peta Lokasi Penelitian

Sumber : hasil citra satelit menggunakan google earth Desember 2019, diolah penyusun tahun 2019 
Kondisi wilayah Pabean yang dikelilingi genangan rob diperparah dengan adanya limbah industri yang dibuang langsung oleh para pelaku industri batik tanpa diolah ke lingkungan sekitar industri yang merupakan permukiman warga. Seperti yang terlihat pada Gambar 3, hal tersebut menjadikan kondisi di sebagian besar kawasan Pabean nampak kumuh, selain itu ketika banjir rob tiba air yang bercampur limbah batik tersebut akan masuk ke pekarangan warga sehingga sangat mengganggu.

(a) Kondisi rumah warga dengan lingkungan
yang digenangi rob
(b) Tempat penjemuran batik yang digenangi
rob bercampur limbah batik

Gambar 3 Kondisi Permukiman Pabean yang Tercemar Limbah Sumber: Hasil observasi penyusun, 2019

Beragam program revitalisasi (Gambar 4) telah dilaksanakan di Pabean dengan dana bantuan pemerintah melalui Program Kotaku maupun lembaga donor lainnya dalam rangka merevitalisasi fungsi sarana dan prasarana yang ada di Pabean seperti pembangunan tower pamsimas, penyediaan MCK umum serta sanimas, perbaikan dan perkerasan jalan desa hingga gang permukiman dan lain sebagainya, yang bertujuan untuk meningkatkan kualitas lingkungan permukiman di Pabean. 


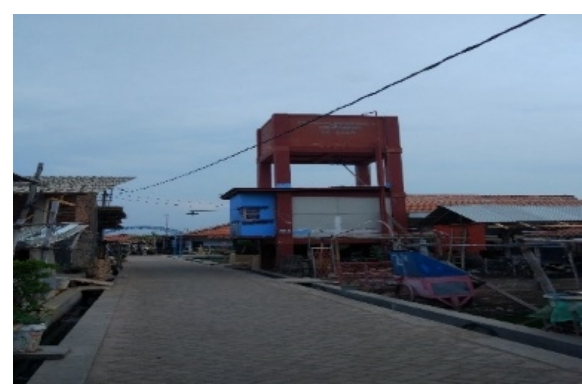

(a) Pembangunan menara air sebagai sumber air bersih warga Pabean

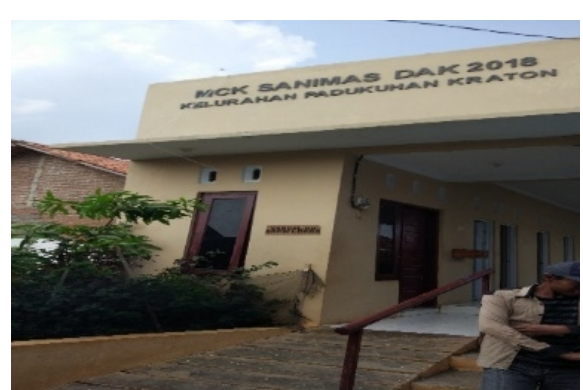

(b) Pembangunan MCK Sanimas warga Pabean

Gambar 4 Revitalisasi Sarana Prasarana di Pabean

Sumber: Hasil Observasi Penyusun, 2019

\subsection{Kualitas lingkungan Permukiman kawasan Pabean}

Kualitas lingkungan tidak hanya berpengaruh pada pengalaman hidup penduduknya, namun juga terkait dengan peluang dan kesempatan hidup mereka dimana lingkungan yang relatif kurang dikaitkan dengan masalah sosial yang dikecualikan (Paddison, 2012). Kondisi sosial masyarakat di Pabean cukup beragam, namun mayoritas penduduk di Pabean adalah sebagai pelaku industri batik, baik sebagai pengusaha batik ataupun perajin dan buruh batik. Hubungan sosial antara sesama warga di Pabean terlihat sangat guyub, hal itu diperkuat pernyataan lurah Padukuhan Kraton yakni Bapak Supaat yang menyatakan bahwa hampir tidak pernah terjadi konflik antar warga maupun warga dengan sektor swasta yakni pengusaha batik. Hal itu dikarenakan antara warga Pabean dan pengusaha batik memiliki hubungan saling ketergantungan satu sama lain, di satu sisi kehadiran batik di Pabean sebagai peluang sumber pendapatan ekonomi warga Pabean dan disisi sebaliknya pengusaha batik juga membutuhkan tenaga kerja lokal untuk menjalankan usaha batiknya. Kerjasama antar warga di pabean dalam menjaga kualitas lingkungan juga sangat baik, sekretariat BKM Tri Mulia Kaisah mengatakan warga sangat antusias apabila mengikuti kegiatan jumat bersih yang diinstruksikan oleh pemerintah dalam rangka menjaga kebersihan dan kenyamanan lingkungan tempat tinggal mereka. Masyarakat Pabean khususnya para pelaku industri batik menyepakati Hari jumat di Pabean menjadi hari libur bekerja karena warga Pabean mayoritas adalah muslim dan wajib melaksanakan sholat jumat berjamaah. Meskipun begitu apabila ada warga yang masih melaksanaan pekerjaan membatik pada hari jumat mereka tidak mempermasalahkannya. Secara umum ekonomi masyarakat di Pabean masih masuk dalam kategori menengah ke bawah. 
Kualitas lingkungan permukiman di wilayah Pabean memiliki 7 indikator penelitian yang menjelaskan kondisi sosial ekonomi masyarakat, serta lingkungan permukiman wilayah Pabean, yaitu lama tinggal, alasan tinggal, status kepemilikan lahan bangunan pendapatan bulanan, kualitas air sumur, kualitas jaringan drainase, dan kualitas jaringan jalan. Pada tabel 1 menunjukan kondisi permukiman di Pabean dari 92 responden pada delapan indikator dalam variabel permukiman termasuk ke dalam kriteria cukup dengan perolehan skor akhir setelah dilakukan konversi adalah 2. Dari hasil skoring tersebut untuk variabel permukiman, menurut masyarakat Pabean permukiman setempat cukup baik untuk dijadikan sebagai tempat tinggal oleh masyarakat Pabean. Dengan adanya kesadaran untuk bermukim pada suatu pemukiman menjadikan komitment tiap individu untuk tinggal disuatu tempat secara terus menerus. Karena Alasan individu dalam suatu kelompok masyarakat yang lama menjadikan individu tersebut memiliki kepedulian pada lingkungan pemukiman (Chen \& Liu, 2016).

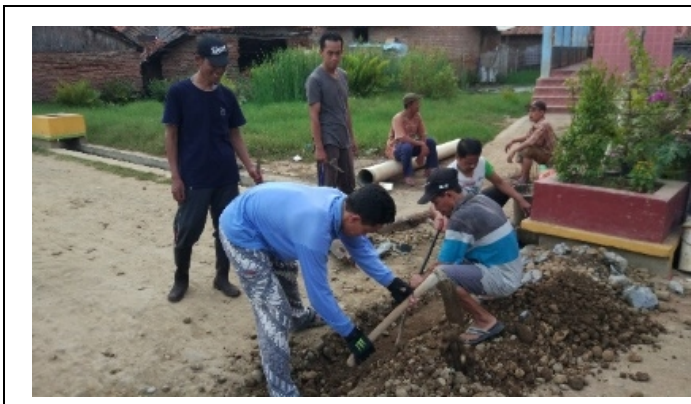

(a) Kegiatan warga membuat sodetan saluran buangan air

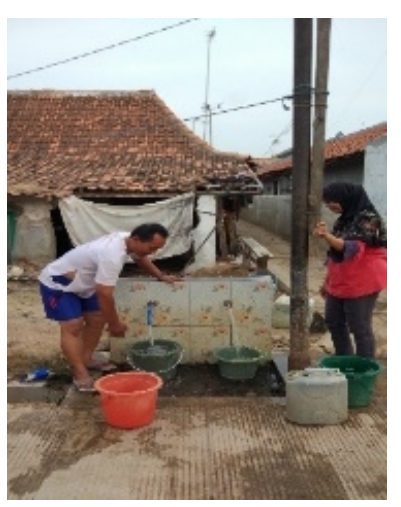

(c) Kegiatan warga pengambilan air bersih melalui saluran pamsimas

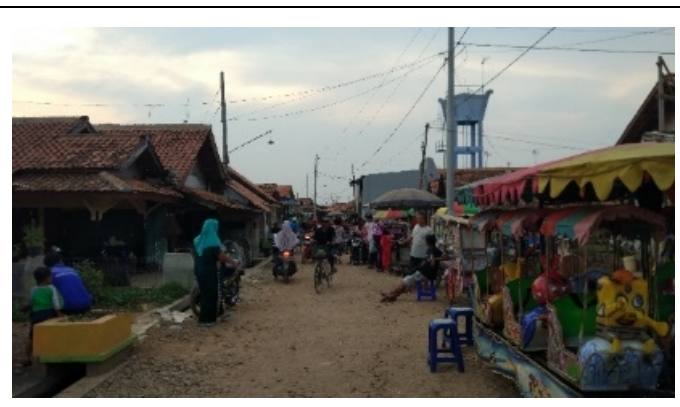

(b) Aktivitas pasar keliling di kawasan Pabean

Gambar 5. Potret Aktivitas Warga Pabean

Sumber: Hasil Observasi Penyusun, 2019 
Tabel 1. Skoring Kualitas Lingkungan Permukiman

\begin{tabular}{|c|c|c|c|c|c|c|c|c|c|c|c|c|}
\hline \multirow[b]{2}{*}{ indikator } & \multicolumn{3}{|c|}{ Baik } & \multicolumn{3}{|c|}{ Sedang } & \multicolumn{3}{|c|}{ Buruk } & \multirow[b]{2}{*}{$\overrightarrow{\underline{\theta}}$} & \multirow{2}{*}{ 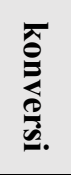 } & \multirow[b]{2}{*}{ 졸. } \\
\hline & 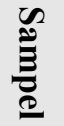 & $\stackrel{n}{\underline{n}}$ & $\vec{e}$ & 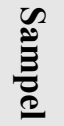 & $\stackrel{n}{\underline{x}}$ & $\overrightarrow{0}$ & 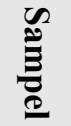 & $\stackrel{n}{\frac{n}{n}}$ & $\overrightarrow{\underline{D}}$ & & & \\
\hline Lama Tinggal & 65 & 3 & 195 & 22 & 2 & 44 & 5 & 1 & 5 & 244 & 2,7 & Baik \\
\hline $\begin{array}{l}\text { Status } \\
\text { Kepemilikan } \\
\text { Lahan / } \\
\text { Bangunan }\end{array}$ & 92 & 3 & 276 & - & 2 & - & - & 1 & - & 276 & 3 & Baik \\
\hline Alasan Tinggal & 2 & 3 & 6 & 39 & 2 & 78 & 51 & 1 & 51 & 135 & 1,5 & Buruk \\
\hline $\begin{array}{l}\text { Pendapatan } \\
\text { Bulanan }\end{array}$ & 1 & 3 & 3 & 35 & 2 & 70 & 56 & 1 & 56 & 129 & 1,4 & Buruk \\
\hline $\begin{array}{l}\text { Kualitas air } \\
\text { sumur }\end{array}$ & - & 3 & - & - & 2 & - & 92 & 1 & 92 & 92 & 1 & Buruk \\
\hline $\begin{array}{l}\text { Kualitas } \\
\text { Jaringan Jalan }\end{array}$ & 4 & 3 & 12 & 81 & 2 & 162 & 7 & 1 & 7 & 181 & 2,0 & Cukup \\
\hline $\begin{array}{l}\text { Kualitas } \\
\text { Drainase }\end{array}$ & 7 & 3 & 21 & 75 & 2 & 150 & 10 & 1 & 10 & 181 & 2,0 & Cukup \\
\hline & & & & & & & & & & & 2 & Cukup \\
\hline
\end{tabular}

Sumber: hasil analisis penyusun, 2019

\subsection{Analisis pengaruh Regenerasi Perkotaan terhadap Kualitas Lingkungan Permukiman Kawasan Pabean}

Dalam menghadapi pengaruh regenerasi yang terjadi pada suatu pemukiman, perlu untuk melihat kembali ketersediaan sumberdaya yang ada pada suatu pemukiman, sehingga permasalahan ekonomi, social, dan perkotaan dapat terhindar (Hassan, 2012).

Tabel 2. Skoring Tiap Variabel per RW

\begin{tabular}{|l|r|r|r|r|r|c|}
\hline \multicolumn{1}{|c|}{ Variabel per RW } & RW 12 & RW 13 & RW 14 & RW 15 & $\begin{array}{r}\text { Rata } \\
\text { Rata }\end{array}$ & Kriteria \\
\hline $\begin{array}{l}\text { Kualitas lingkungan } \\
\text { permukiman }\end{array}$ & 1,83 & 2,12 & 2,4 & 2,21 & 2,1 & Cukup \\
\hline Hubungan Sosial Masyarakat & 2,77 & 3,1 & 3,04 & 3,21 & 3,0 & Baik \\
\hline $\begin{array}{l}\text { Peran sektor swasta dan } \\
\text { pemerintah dalam lingkungan }\end{array}$ & 1,12 & 1,35 & 1,62 & 1,5 & 1,4 & Buruk \\
\hline $\begin{array}{l}\text { Hubungan Masyarakat dengan } \\
\text { sektor swasta dan pemerintah }\end{array}$ & 1,76 & 1,92 & 2,17 & 2,24 & 2,0 & Cukup \\
\hline \multicolumn{1}{|c|}{ TOTAL } & $\mathbf{1 , 8 7}$ & $\mathbf{2 , 1 9}$ & $\mathbf{2 , 2 4}$ & $\mathbf{2 , 2 9}$ & \multicolumn{2}{|c}{} \\
\hline
\end{tabular}

Sumber: hasil analisis penyusun, 2019 
Pada tabel 2 diatas menunjukaan bahwa kondisi tiap variabel penelitian memiliki kondisi yang beragam dengan skor tertinggi pada variabel hubungan sosial masyarakat, serta skor terendah terdapat pada variabel peran sektor swasta dan pemerintah dalam menjaga kualitas lingkungan. Apabila dilihat dari masing - masing RW yang ada di Pabean, maka dapat dijelaskan hal sebagai berikut:

1. Pada variabel kualitas lingkungan permukiman memiliki skor terbesar pada RW 14 dan dilanjutkan RW 15, RW 13 dan RW 12. Hasil analisis tersebut menunjukkan bahwa kualitas lingkungan permukiman paling baik terdapat pada RW 14 karena masyarakat RW 14 memiliki kondisi sosial, ekonomi, dan lingkungan yang baik, sehingga dapat disimpulkan bahwa RW 14 memiliki kualitas dan kehidupan permukiman yang baik dan pengaruh yang ditimbulkan dari regenerasi perkotaan terhadap permukiman RW 14 adalah baik.

2. Pada variabel hubungan sosial masyarakat yang merupakan salah satu variabel terkait konsep regenerasi perkotaan pada lingkungan permukiman Pabean memiliki perolehan skor terbesar pada RW 15 dan dilanjutkan RW 14, RW 13 dan RW 12. Hasil analisis tersebut menunjukaan bahwa hubungan sosial masyarakat Pabean paling baik ada di RW 15 dikarenakan masyarakatnya guyub dan tidak pernah terjadi konflik sehingga dapat mempengaruhi lama tinggal di wilayah tersebut.

3. Pada peran sektor swasta dan pemerintah dalam menjaga kualitas lingkungan yang merupakan salah satu variabel terkait konsep regenerasi perkotaan pada lingkungan permukiman Pabean memiliki perolehan skor terbesar pada RW 14 dan dilanjutkan RW 15, RW 13 dan RW 12. Hasil analisis tersebut menunjukaan bahwa dibanding dengan RW lain di Pabean masyarakat RW 14 lebih menyatakan bahwa peran sektor swasta dan pemerintah memiliki peranan yang agak lebih baik dalam menjaga kualitas lingkungan permukiman. Walaupun peran dari pemerintah yang lebih menonjol dibanding dengan peran swasta untuk menjaga kualitas lingkungan permukiman.

4. Pada variabel hubungan masyarakat dengan swasta dan pemerintah yang merupakan salah satu variabel terkait konsep regenerasi perkotaan pada lingkungan permukiman Pabean memiliki perolehan skor terbesar pada RW 15 dan dilanjutkan RW 14, RW 13 dan RW 12. Hasil analisis tersebut menunjukaan bahwa dibanding dengan RW lain di Pabean masyarakat RW 15 memiliki hubungan yng paling baik dengan sektor 
swasta dan pemerintah, dengan adanya keterlibatan yang baik dari masyarakat serta partisipasi masyarakat dapat mempengaruhi kondisi yang kondusif di Pabean.

Untuk mengetahui seberapa besar pengaruh dari regenerasi perkotaan terhadap permukiman di wilayah Pabean secara keseluruhan, maka dilakukan analisis regresi linier berganda dengan menggunakan tiga variabel penelitian terkait konsep regenerasi perkotaan sebagai variabel independen, yaitu variabel hubungan sosial masyarakat, peran sektor swasta dan pemerintah dalam menjaga kualitas lingkungan permukiman serta hubungan antara masyarakat dengan sektor swasta dan pemerintah. Terhadap satu variabel dependen yakni kualitas lingkungan permukiman.

Tabel 3. Hasil Uji Regresi Linier Berganda

\begin{tabular}{|c|c|c|c|c|c|c|}
\hline \multicolumn{7}{|c|}{ Coefficients $^{\mathrm{a}}$} \\
\hline \multirow{2}{*}{\multicolumn{2}{|c|}{ Model }} & \multicolumn{2}{|c|}{ Unstandardized Coefficients } & \multirow{2}{*}{$\begin{array}{c}\text { Standardized } \\
\text { Coefficients } \\
\text { Beta }\end{array}$} & \multirow[t]{2}{*}{$\mathrm{t}$} & \multirow[t]{2}{*}{ Sig. } \\
\hline & & B & Std. Error & & & \\
\hline \multirow[t]{4}{*}{1} & (Constant) & 12.081 & 4.390 & & 2.752 & .007 \\
\hline & (X1) Hub Sos Masy & .652 & .724 & .088 & .900 & .371 \\
\hline & $\begin{array}{l}\text { (X2) Peran Swasta dan } \\
\text { Pemerintah }\end{array}$ & .159 & .071 & .284 & 2.243 & .027 \\
\hline & $\begin{array}{l}\text { (X3) Hub Masy dengan } \\
\text { swasta dan pemerintah }\end{array}$ & -.110 & .081 & -.174 & -1.366 & .175 \\
\hline
\end{tabular}

Sumber: Hasil analisis penyusun, 2019

Berdasarkan hasil analisis regresi linier berganda pada tabel Dengan menggunakan aplikasi SPSS 22. Maka diperoleh persamaan regresi sebagai berikut:

$\mathrm{Y}=12.081+0.652 \mathrm{X} 1+0.159 \mathrm{X} 2-0.110 \mathrm{X} 3+\mathrm{e}$

Persamaan regresi linier berganda tersebut mengandung arti bahwa:

1. Konstanta sebesar 12.081 menyatakan bahwa, jika variabel hubungan sosial masyarakat (X1), peran swasta dan pemerintah dalam menjaga kualitas lingkungan (X2), dan Hubungan antara masyarakat dengan Swasta dan Pemerintah (X3) nilainya adalah 0 , maka variabel kualitas dan kehidupan permukiman (Y) adalah sebesar 12.081

2. Koefisien regresi variabel hubungan masyarakat (X1) adalah 0.652 yang menyatakan bahwa jika variabel X1 mengalami kenaikan 1 satuan, dan variabel X2 dan X3 bernilai tetap, maka variabel kualitas dan kehidupan permukiman (Y) akan mengalami kenaikan sebesar 0.652. Koefisien bernilai positif artinya terjadi hubungan positif antara variabel X1 terhadap variabel Y. Semakin tinggi hubungan sosial masyarakat Pabean, maka semakin tinggi pula kualitas lingkungan permukiman di Pabean. 
Jurnal Planologi Vol. 17 No. 2, Oktober 2020

Available : http://jurnal.unissula.ac.id/index.php/psa

3. Koefisien regresi variabel peran sektor swasta dan pemerintah dalam menjaga kualitas lingkungan (X2) adalah 0.152 yang menyatakan bahwa jika variabel X3 mengalami kenaikan 1 satuan dan variabel X1, X3 tetap, maka variabel kualitas lingkungan permukiman (Y) akan mengalami kenaikan sebesar 0.152. Koefisien bernilai positif artinya terjadi hubungan positif antara variabel X2 dan variabel Y. Semakin tinggi peran sektor swasta dan pemerintah dalam menjaga kualitas air sumur, jaringan jalan, dan drainase maka semakin baik pula kualitas lingkungan permukiman Pabean.

4. Koefisien regresi variabel hubungan masyarakat dengan sektor swasta dan pemerintah (X3) adalah -0.110 yang menyatakan bahwa jika variabel X1 dan X2 bernilai tetap maka variabel kualitas dan kehidupan permukiman (Y) akan mengalami penurunan sebesar 0.110 . Koefisien bernilai negatif artinya terjadi hubungan yang negatif antara variabel X3 dengan variabel Y. Semakin tinggi hubungan antara masyarakat dengan swasta dan pemerintah bisa menyebabkan menurunnya kualitas lingkungan permukiman Pabean.

Tabel 4. Hasil Uji Kelayakan Model Regresi Linier

\begin{tabular}{|c|c|c|c|c|c|c|}
\hline \multicolumn{7}{|c|}{ ANOVA $^{\mathbf{a}}$} \\
\hline \multicolumn{2}{|c|}{ Model } & \multirow{2}{*}{$\begin{array}{r}\begin{array}{l}\text { Sum of } \\
\text { Squares }\end{array} \\
9.692 \\
\end{array}$} & \multirow{2}{*}{$\begin{array}{r}\text { df } \\
3 \\
\end{array}$} & \multirow{2}{*}{$\begin{array}{l}\begin{array}{l}\text { Mean } \\
\text { Square }\end{array} \\
3.231\end{array}$} & \multirow{2}{*}{$\begin{array}{l}\mathrm{F} \\
6.312\end{array}$} & \multirow{2}{*}{$\begin{array}{l}\text { Sig. } \\
.001^{\mathrm{t}}\end{array}$} \\
\hline 1 & Regression & & & & & \\
\hline & Residual & 45.036 & 88 & .512 & & \\
\hline & Total & 54.728 & 91 & & & \\
\hline \multicolumn{7}{|c|}{ a. Dependent Variabel: (Y) Kualitas Lingkungan permukiman } \\
\hline \multicolumn{7}{|c|}{$\begin{array}{l}\text { b. Predictors: (Constant), (X3) Hub Masy dengan swasta dan pemerintah, (X1) Hub } \\
\text { Sos Masy, (X2) Peran Swasta dan Pemerintah }\end{array}$} \\
\hline
\end{tabular}

Uji kelayakan model regresi atau disebut juga sebagai uji simultan model yang dilakukan untuk mengidentifikasi apakah model regresi yang diestimasi layak atau tidak. Layak yang dimaksud adalah model yang diestimasi layak digunakan untuk menjelaskan pengaruh variabel - variabel independen terhadap variabel dependen. Kelayakan dilihat dari nilai prob. F htung (ditunjukan kolom Sig) menunjukkan angka lebih kecil dari tingkat kesalahan sebesar 0.05 maka dapat dikatakan bahwa model regresi layak digunakan untuk menjelaskan pengaruh prediktor atau variabel hubungan sosial masyarakat (X1), pengaruh swasta dan pemerintah dalam menjaga kualitas lingkungan (X2) dan hubungan masyarakat dengan swasta dan pemerintah (X3) yang merupakan variabel independen, terhadap 
Jurnal Planologi Vol. 17 No. 2, Oktober 2020

Available : http://jurnal.unissula.ac.id/index.php/psa

variabel kualitas lingkungan permukiman (Y) sebagai variabel dependen. Sehingga diketahui pada penelitian ini, variabel independen memiliki pengaruh terhadap variabel dependen.

Tabel 4. Hasil Koefisien Determinasi Simultan R2

\begin{tabular}{|l|c|c|c|c|c|}
\hline \multicolumn{7}{|c|}{ Model Summary } \\
\hline $\begin{array}{l}\text { Mod } \\
\text { el }\end{array}$ & $\mathrm{R}$ & $\begin{array}{c}\mathrm{R} \\
\text { Square }\end{array}$ & $\begin{array}{c}\text { Adjusted R } \\
\text { Square }\end{array}$ & $\begin{array}{c}\text { Std. Error of } \\
\text { the Estimate }\end{array}$ & $\begin{array}{c}\text { Durbin- } \\
\text { Watson }\end{array}$ \\
\hline 1 & $.421^{\mathrm{a}}$ & .177 & .149 & .71539 & .432 \\
\hline \multicolumn{5}{|l}{ a. Predictors: (Constant), (X3) Hub Masy dengan swasta dan pemerintah, (X1) } \\
Hub Sos Masy, (X2) Peran Swasta dan Pemerintah \\
\hline \multicolumn{4}{|l}{ b. Dependent Variabel: (Y) Kualitas Lingkungan permukiman } \\
\hline
\end{tabular}

Sumber: hasil analisis penyusun, 2019

Hasil Adjusted R Square sebesar 0,149 maka dapat disimpulkan bahwa adanya pengaruh dari variabel yang merupakan konsep regenerasi kota yakni hubungan sosial masyarakat, peran swasta dan pemerintah dalam menjaga kualitas lingkungan dan hubungan masyarakat dengan swasta dan pemerintah terhadap kualitas lingkungan permukiman di Pabean sebesar 14,9\% dan sisanya sebesar 85,1 \% dipengaruhi oleh variabel lain yang tidak ada dalam model regresi linier. Dari analisis yang dilakukan dengan metode regresi linier berganda, maka diketahui bahwa secara keseluruhan, pengaruh regenerasi perkotaan terhadap kualitas lingkungan permukiman Pabean sebesar 14,9 \% dengan pengaruh terbesar terjadi pada lingkungan RW 14 dan RW 15. Hal ini berarti bahwa dari masing - masing variabel peneltian terkait regenerasi perkotaan memiliki pengaruh yang tidak besar terhadap variabel permukiman. pengaruh paling besar terjadi pada variabel peran swasta dan pemerintah dalam menjaga kualitas lingkungan permukiman dimana seperti pada analisis skoring yang telah dilakukan sebelumnya, banyak terjadi penurunan kualitas lingkungan permukiman akibat aktivitas dari sektor batik yang tidak mengelola limbah dengan baik sehingga langsung masuk ke drainase warga dan menyebabkan gangguan visual, pencemaran udara serta ancaman kesehatan.

\section{KESIMPULAN DAN SARAN}

\subsection{Kesimpulan}

Hal yang paling penting tentang regenerasi kota adalah keharusan bagi semua bidang kebijakan publik dan swasta untuk dapat menjalankan fungsinya dalam nilai-nilai pembangunan berkelanjutan, ekonomi, sosial, lingkungan dan politik. 
Dari hasil penelitian dapat disimpulkan bahwa berdasarkan hasil analisis regresi linier berganda dengan melakukan regresi pada tiga variabel bebas (hubungan sosial masyarakat, peran swasta dan pemerintah dalam pengelolaan kualitas lingkungan, dan hubungan antara masyarakat dengan swasta dan pemerintah) terhadap satu variabel terikat (kualitas lingkungan permukiman), menunjukkan bahwa terdapat pengaruh sebesar 14,29 persen dari adanya kegiatan regenerasi perkotaan terhadap kualitas lingkungan permukiman di kawasan Pabean. Maka hasil dari penelitian ini diketahui bahwa secara keseluruhan, pengaruh dari regenerasi perkotaan terhadap kualitas lingkungan permukiman di kawasan Pabean menunjukkan bahwa dari masing - masing variabel penelitian terkait regenerasi perkotaan memiliki pengaruh yang tidak begitu besar terhadap variabel permukiman.

Terjadinya regenerasi perkotaan untuk menunjang nilai perekonomian kota pada lingkungan permukiman tengah kota seperti di Pabean, dapat mendorong perubahan ke arah yang lebih positif, terlihat dari koefisien hubungan social masyarakat yang memiliki nilai t sebesar 0.900 dan peran swasta dan pemerintah dalam menjaga lingkungan yang memiliki nilai $\mathrm{t}$ sebesar 2.243. Selain dampak positif yang dihasilkan tentunya terdapat dampak negatif pada lingkungan permukiman kawasan Pabean, hal itu dapat terlihat dari tabel koefisien yakni hubungan masyarakat dengan swasta dan pemerintah menunjukkan nilai -1.366. Pada kenyataannya regenerasi tidak akan membuat kehilangan atau bahkan mengurangi kualitas lingkungan tempat tinggal kecuali jika masyarakat dan pemerintah, sektor swasta dan keduanya tidak memiliki hubungan kerja sama satu sama lain yang menarik dalam regenerasi kota.

Beberapa saran yang dapat diberikan kepada para pihak yang terkait yakni pemerintah, masyarakat, dan sektor swasta agar dapat secara bersama menciptakan perkotaan yang kondusif secara sosial, ekonomi, dan lingkungan, sebagai berikut:

\subsection{Saran}

\section{A. Saran bagi Pemerintah}

Perlunya pihak pemerintah untuk menumbuhkan kohesi sosial di lingkungan masyarakat kawasan Pabean supaya masyarakat memiliki keperdulian terhadap lingkungan tempat mereka bermukim. Pemerintah juga perlu terus menyokong masyarakat supaya lebih aktif dalam segala aktivitas pembangunan yang dicanangkan pada lingkungan permukiman di kawasan Pabean. Kemudian kerjasama sektor swasta dan pemerintah perlu 
Jurnal Planologi Vol. 17 No. 2, Oktober 2020

Available : http://jurnal.unissula.ac.id/index.php/psa

ditingkatkan demi menjaga dan meningkatkan kualitas lingkungan yang lebih baik lagi pada permukiman di Pabean.

\section{B. Saran Bagi Masyarakat}

Adaptasi dan kesiap tanggapan dari masyarakat perlu ditingkatkan lagi terhadap kondisi lingkungan Pabean sehingga mampu memahami apa yang akan terjadi pada lingkungan mereka bermukim apabila mereka acuh tak acuh terhadap kondisi sekitar. Perlunya peningkatan partisipasi dan keterlibatan masyarakat secara aktif dalam pengambilan keputusan sehingga diharapkan dapat mendorong kualitas lingkungan yang lebih baik lagi.

\section{Saran Bagi Swasta}

Untuk menghindari kesenjangan antara sektor swasta dan masyarakat, dalam rangka peningkatan kualitas lingkungan permukiman di Pabean sudah seyogyanya ada kegiatan swasta yang melibatkan masyarakat sekitar. Sektor swasta harus lebih peduli lagi terhadap limbah yang mereka hasilkan dengan melakukan pengolahan limbah terlebih dahulu setelah layak untuk dibuang baru bisa dilepas ke sungai. Peran swasta terhadap kualitas lingkungan juga wajib dilaksanakan, perlu adanya tim pengawasan terhadap sektor swasta yang tidak mau terlibat dapat diberikan sanksi atau hukuman tertentu.

\section{DAFTAR PUSTAKA}

Alpopi, C., \& Manole, C. (2013). Integrated Urban Regeneration - Solution for Cities Revitalize. Procedia Economics and Finance. https://doi.org/10.1016/s22125671(13)00130-5

Ardiati, H. H. (2017). Pengaruh Regenerasi Perkotaan Terhadap Permukiman Kelurahan Pekunden Kota Semarang. Universitas Diponegoro.

Balaban, O., \& Puppim de Oliveira, J. A. (2014). Understanding the links between urban regeneration and climate-friendly urban development: lessons from two case studies in Japan. Local Environment. https://doi.org/10.1080/13549839.2013.798634

Chen, S., \& Liu, Z. (2016). What determines the settlement intention of rural migrants in China? Economic incentives versus sociocultural conditions. Habitat International. https://doi.org/10.1016/j.habitatint.2016.09.004

Comte, A. (1975). Auguste Comte and positivism: The essential writings. Transaction Publishers.

de Magalhães, C. (2015). Urban Regeneration. In International Encyclopedia of the Social 
Jurnal Planologi Vol. 17 No. 2, Oktober 2020

Available : http://jurnal.unissula.ac.id/index.php/psa

\& Behavioral Sciences: Second Edition. https://doi.org/10.1016/B978-0-08-097086$8.74031-1$

Doxiadis, C. A. (1970). Ekistics, the science of human settlements. Science. https://doi.org/10.1126/science.170.3956.393

Farr, D. (2008). Where We Need to Go. In Sustainable urbanism: urban design with nature.

Hassan, G. F. (2012). Regeneration as an approach for the development of informal settlements in Cairo metropolitan. Alexandria Engineering Journal. https://doi.org/10.1016/j.aej.2012.02.003

Houk, M., Koutsomarkou, J., Moulin, E., Scantamburlo, M., \& Tosics, I. (n.d.). Sustainable regeneration in urban areas, URBACT II capitalisation, April 2015. Retrieved from http://urbact.eu

Paddison, R. (2012). Housing and neighbourhood quality. Urban regeneration. In International Encyclopedia of Housing and Home. https://doi.org/10.1016/B978-008-047163-1.00228-9

Roberts, P., Sykes, H., \& Granger, R. (2000). Handbook for Urban Regeneration. In Sage.

Roberts, P., Sykes, H., Granger, R., Roberts, P., Sykes, H., \& Granger, R. (2016). Current Challenges and Future Prospects. In Urban Regeneration. https://doi.org/10.4135/9781473921788.n16

Turcu, C. (2012). Local experiences of urban sustainability: Researching Housing Market Renewal interventions in three English neighbourhoods. Progress in Planning. https://doi.org/10.1016/j.progress.2012.04.002 